\title{
Heraclitus from Ephesus on the strength of mind
}

Keywords: Heraclitus, neurosciences, neurophilosophy, word, mind, wisdom, human prosperity

\section{Editorial}

Heraclitus is one of the most eminent philosophers of the Ionian school of philosophy. He was born in Ephesus, a prosperous city of Asia Minor, at the beginning of the fifth century B.C. in the 69th Olympiad. ${ }^{1}$ He used to live in solitude, thinking, meditating, and writing, leading a genuine ascetic mode of life, endeavoring to investigate, analyze and know himself in depth. ${ }^{2}$ The style of his life had a melancholic feeling, ${ }^{3}$ and the profile of his personality was characterized by unique honesty, gentleness, liberalism, strength, and magnanimity. His life had a tragic epilogue, given that he suffered from abdominal edema, presumably due to cirrhosis of the liver, and deceased isolated and helpless in a stable, at the age of sixty.

From his valuable writings, ${ }^{4}$ few fragments only survived plenty of wisdom and originality, which were mostly cited and incorporated in the manuscripts of a substantial number of other philosophers and early Christian authors. ${ }^{5}$ Heraclitus's expressive style is characterized by density, opacity, resonance, metaphor, symbolism, axioms, critisism and solemnity. Thus, many of his fragments might be interpreted under various viewpoints. Nevertheless, Heraclitus is one of the most extensively studied, cited, esteemed, respected, and even admired preSocratic philosophers, who have had a great impact on the philosophy and the literature for ages, ${ }^{6}$ given that his doctrines were gaining the admiration of Plato, Aristotle, Stoics, ${ }^{7,8}$ Sextus Empiricus, Porphyrius, St. Augustin, ${ }^{9}$ Hölderlin, Hegel, ${ }^{10}$ Kierkegaard, ${ }^{11,12}$ Nietzche, ${ }^{13}$ Heidegger, ${ }^{14,15}$ Jung, Eliot, ${ }^{16}$ Ibsen, Kafka ${ }^{17}$ and many others.

Heraclitus as an author introduced the concept of Logos ( $\Lambda$ ó Word $),{ }^{18}$ which remains intact forever and is accessible to any thinker because it is common, clear and universal. Everything was created by Logos. Logos is the central idea of crucial importance for the approaching and understanding of the Being. ${ }^{19}$ All human legislation and rules have one celestial universal source that is the Logos (the Word).$^{19}$ Heraclitus implored that every human being should listen to the Word and know a simple truth, that "all is one", which is the supreme message of wisdom. ${ }^{20}$

On the soul Heraclitus claims that none would ever discover the limits of the psyche, should one transverse every existing road, given that psyche's dimensions, are immense, possessing a deep and inaccessible measure. ${ }^{21}$ According to Heraclitus the psyche, understanding the truths has also unlimited resources. ${ }^{22}$ Psyche itself is the source not only of life but also of reason and rational control of human behavior. The psyche should be purified from all the passions, vices, and weakness and particularly from the insolation (hybris). However, it is always difficult for human beings to overcome their passions and feelings.

The noble-minded man focuses himself in silence ${ }^{23}$ on everlasting values and truths, rather than on transient and superfluous thinks. The character of a person plays a decisive role in his mode of life and his fate eventualy. The souls of the best, the honest, the righteous, and the virtuous seem to be assured of deification and immortality. ${ }^{24}$

According to Heraclitus, the concepts of Logos, Truth, Nature,
Volume II Issue 2 - 202 I

\author{
Stavros J Baloyannis \\ Professor Emeritus, Research Institute for Alzheimer's disease, \\ Aristotelian University, Greece
}

Correspondence: Stavros J Baloyannis, Professor Emeritus, Research Institute for Alzheimer's disease, Aristotelian University, Angelaki 5, Thessaloniki 54621, Greece, Tel +302310270434; Fax +302310270434; Email sibh844@otenet.gr

Received: March 08, 202I | Published: April 02, 2021

and Eternity are the crucial existential principles for the Being and the "Wise is one thing, to be acquainted with true judgment, how all things are steered through all». Thinking is an essential property to all men. Wisdom is the unique capacity of the mind that guides, interpenetrates, and interpret all things. Wisdom, being a unique experience, is apart from mediocrity and is isolated from the numerous exterior imposing influences. ${ }^{25}$ Spiritual light illuminates the mind and controls righteously the rhythms of the personal internal life. Thinking profoundly is a great and essential virtue and wisdom consists in telling the truth and acting following the real meaning and constitution of things. ${ }^{26} \mathrm{An}$ excellent man is equivalent to ten thousand poeple. ${ }^{27}$ Learning is not the only path of wisdom, ${ }^{28}$ given that the profound knowledge based on experience and gained by inquiry into a wide spectrum of things may help in uncovering the reality and the existential truth, which mostly lie opaque or esoteric.

The universe is a continuous state of dynamic equilibrium of many entities, whereas at the same time «all things are one». Heraclitus frequently asserts the unity of opposites, ${ }^{29}$ thus «the road up and

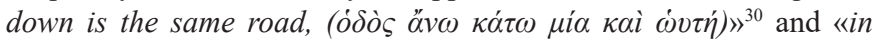
the circumference of the circle beginning and end are the same». ${ }^{31}$ Heraclitus claims that everything is in flux, as the constant flow of a river, insisting that «nobody can step twice into the same river».32, ${ }^{33}$ Thus, energy influx is the essence of the matter. Moreover, energy becomes matter and matter becomes energy. Energy is always regenerated since the sun is new again every day.The world as a whole is an everlastingly repeated sequence of cycles, each of which emerges out of the fire and ends in fire finally, given that fire is the underlying principle of all things ( $\pi \dot{\alpha} v \tau \alpha \gamma \alpha \dot{\alpha} \rho \tau \dot{o} \pi \tilde{v} \rho \dot{\varepsilon} \pi \varepsilon \lambda \theta \dot{o} v \kappa \rho \imath v \varepsilon i \tilde{i} \kappa \alpha i ̀$ $\kappa \alpha \tau \alpha \lambda \eta \dot{\psi} \psi \varepsilon \tau \alpha l) .{ }^{34}$

Life and death are in a constant continuation and not in opposition, just like any point of the circle's circumference, where beginning and end are common, depending on the perspectives from which it is accepted..$^{35}$ The brightness of the sunlight, like the truth, surrounds covers everything. Seeing is grasping in light and spiritual seeing is grasping in truth. ${ }^{36}$ Spiritual or celestial light never extinguishes. The personal time or the interior aspect of time is a changeable parameter that depends upon the interior harmony and the actual psychological condition of the person. ${ }^{37}$ The lack of consciousness entails a lack of personal time and profound dementia entails timeless time. ${ }^{38}$

The main issue for the human being is the quality of life and immortality in death, ${ }^{39}$ which is the subject of long meditation and 
the starting point of a continuous spiritual endeavoring. ${ }^{40}$ Frequently Heraclitus expresses an obvious mysticism stating that «nature loves to hide, $\varphi v ́ \sigma l \varsigma \kappa \rho v i \pi \tau \varepsilon \sigma \theta \alpha l \varphi \imath \lambda \varepsilon \tilde{i}\rangle^{41}$ and «an unapparent harmony is stronger than an apparent one». Even more than that Heraclitus claimed that «Immortals are mortals, mortals are immortals, living their death, dying their life". ${ }^{42}$

The message of Heraclitus to our suffering unstable society is that prosperity is not synonymous with income, wealth, or economic elevation, since it has primarily vital personal, existential, psychological, social, and spiritual dimensions. Prosperity substantially means a meaningful life of the man ${ }^{43}$ who retaining his interior peace, stability, and harmony of the soul, ${ }^{44}$ can cordially offer and gain love, appreciation, and compassion, respecting deeply the others and enjoying the respect of them. Besides, the prosperity of the society is mainly based on the moral values, the wisdom, the truth, the illumination of the mind, the brightness of the soul, and on the

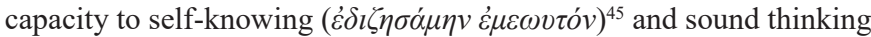
of the citizens. A prosperous society can only be conceived as one in which the citizens would live in noble simplicity, loyalty, honesty, purity, solidarity, reliability, in light, overpassing any crisis properly, by the strength of mind.

Heraclitus could be characterized as the first real existential philosopher, whose ideas have been revitalized, expressed and exposed more systematically, emphatically, and acceptably in the broad fields of modern existential philosophy ${ }^{46}$. According to Heraclitus the purification of the soul from the passions, the ambition, the egoism and mainly from vulgarity and impertinence should be the most important mission of the human being because there is greatest need to extinguish impertinence from the society than a blazing fire. A prosperous society can only be established, whenever people would decide to live in noble simplicity, incorruptibility, interior peace, purity of heart, compassion, solidarity, searching for the truth, contemplating the strength of mind.

\section{Acknowledgments}

None.

\section{Conflicts of interest}

The authors declare no conflicts of interest.

\section{References}

1. McKirahan RD. Philosophy before Socrates: An introduction with texts and commentary. Indianapolis 1994

2. Plutarch Moralia. Adversus Colotem, Gregorius N. Bernardakis. Leipzig. Teubner. 1895.

3. M Marcovich. Diogenes Laertius: Vitae Philosophorum, 2 vols., Vol. I: Libri I-X; Vol. II: Excerpta Byzantina. Stuttgart and Leipzig BG Teubner, 1999.

4. Kirk GS, Raven JE, Schofield M. The Presocratic Philosophers: A critical History with a selection of texts. $2^{\text {nd }}$ edn. Cambridge University Press. 1995.

5. Pierron A. Histoire de la Littırature Grecque, Septième édition, Hachette, Paris. 1875

6. Lasslae F. The philosophy of Heracletus the obscure of Ephesus. Two volumes, Berlin. 1858.

7. Epicteti Dissertationes ab Arriani digestae H. Schenkl, Stutgardiae aed. Teubneri. 1965
8. Long AA. Stoic studies, Cambridge, Cambridge University Press. 1996.

9. St. Augustine's Confessions Vol I \& ÉI. Transl. W. Watts Loeb Classical Library, Cambridge, Mass. Harvard University Press. 1977.

10. Hegel GWF. Lectures on the History of Philosophy ed. Hoffmeister. 1940.

11. Gouwens D. Kierkegaard as Religious Thinker: Passions, Virtues and praxis, Cambridge University Press, Cambridge. 1996.

12. Kierkegaard S. Concluding Unscientific Postscript. Princeton University Press. 1944.

13. Nietsche F. Filosophie im tragischen Zeitalter der Griechen Ed.M.Cowan, Chicago. 1962.

14. Heidegger M. Einfuhrung in die Metaphysik, Tubingen: Max Niemeyer Verlag, 1953.

15. Heidegger M. Sein und Zeit, Tübigen. 16 ed. Max Niemeyer Verlag. 1986

16. Eliot TS. Collected Poems. London, Faber. 1974.

17. Cooper L. The Greek genius and its influence Ithaca. New York: Cornell University Press. 1952.

18. Graham D. Heraclitus' Criticism of Ionian Philosophy. In: CCW Taylor. Oxford Studies in Ancient Philosophy, Oxford University Press, 1997; 15:1-50.

19. Diels H, Kranz W, Die Fragmente der Vorsokratiker, Berlin: Weidmannsche Verlags- buchhandlung, 1951.(Fragment. B2).

20. Fragm. DK22 B10.

21. Fragm. DK22 B 45.

22. Migne St. Gregory the Theologian, P.G.35, 913 C.

23. Gross J. La divinisation du chrètien d' après les Péres grecs; contribution historique $\alpha$ la doctrine de la grâce, Paris. 1938, p. 344.

24. Fragm.DK22 B35. Clement Stromateis V, 141.

25. Fragm. DK22 B29.

26. Fragm. DK22 B49.

27. Fragm. DK22 B41, Diog.Laertius.IX,1

28. Fragm. DK22 B80. Origen, Against Celcus I 42.

29. Fragm. DK22 B60.

30. Fragm. DK22 B103.

31. Fragm. DK22 B91.

32. Vlastos G. On Heracletos. Am J Philosophy. 1955;76:337-368.

33. Fragm.DK22 B66.

34. Keizer H. Life, Time, Eternity. A Study of AIVN in Greek Literature, Amsterdam, Universiteit van Amsterdam. 1999.

35. Lossky V. The vision of God. The faith Press, Bedfordshire. 1973.

36. Fragment.DK22 B51. Hippolytus, Refutation of all heresies IX $\alpha$.

37. Baloyannis S. The philosophy of dementia. Encephalos. 2010;47:109 130.

38. Nussbaum MC. Psyche in Heraclitus. Phonesis 1972;17:1-16.

39. Fragm. DK22 B84.

40. Fragm. DK22 B123. 

41. Fragm. DK22 B62.
42. Fragm. DK B112.
43. Fragm. DK22 B115.
44. Fragm.DK22 B101.

45. Fragm. DK22 B42.

46. Kahn C. The art and thought of Heraclitus, Cambridge. 1979.

47. Baloyannis SJ. The philosophy of Heraclitus today. Encephalos. 2013;50:1-21. 